\title{
Agriculture Landuse Pattern in Solapur District of Maharashtra
}

\author{
Todkari G.U.*1 ${ }^{*}$ Suryawanshi S.P. ${ }^{2}$, Suryawanshi M.V.. and Patil B.D. ${ }^{4}$ \\ Department of Geography, Shri Sant Damaji Collage, Mangalwedha, Solapur, MS, India \\ Department of Geography, Vidyan Mhahavidhalaya, Sangola, Solapur, MS, India \\ Department of Geography, Dr BAM University, Aurangabad, MS, India \\ Department of Geography, SCS College, Omerga-Osmanabad, MS, India
}

\begin{abstract}
In this paper an attempt has been made to analyse the agricultural landuse pattern at micro level in Solapur District. This study is based on secondary data collected from secondary records. Agriculture production is influenced by physical, climatological, socio-economic, technological and organization factors. An Endeavour is made here to study crop combination regions in Solapur District for year 2004-2005. This is normal year for agriculture phenomenon in this district. The crop data has been computed with the help of Weaver's technique of crop combination. Solapur district occupies southern part of Maharashtra state. It occupies an area of 14,84559 sq.km. And supports 32.32 lack of population in 2001 censes. Administrative the district is divided in to eleven tahsils. Physiography, temperature, rainfall, soil and drainage influence on agriculture landuse pattern in this district. Temperature is high in summer. Because of district is located in drought prone area of Maharashtra. Rainfall varies between 200 to 600 millimeters rainfall from west to east in entire district. Thirteen crops have been considered for crop ranking and crop combination. Among these, jawar, wheat, bajara, sugarcane, gram, maize, safflower, cotton, etc. are the major crops. By computing crop ranks and crop combination in Solapur District has identified ten crop combination. Such type of study represents real situation of cropping pattern in Solapur District and helps to planners, agricultural scientists and research scholars.
\end{abstract}

Keywords: Landuse pattern, crop ranking, crop combination, cropping pattern

\section{Introduction}

Agriculture still forms the backbone of Indian economy, inspite concerned efforts towards industrialization in last three decades. Agriculture contributes a high share of net domestic product by sectors in India. Farmers are growing numerous of crops in the field rather than single crop. The distributional pattern of crops in any region is an outcome of predominance of certain crop or combination of crops. This is an term of emergence of typical crop combination. Cropping pattern in study region has undergone an evolutionary process. The soil and other natural environmental factors, along with the socioeconomic factors, affects the cropping pattern in study region. The statistical techniques provide accurate techniques. For the study of agriculture landuse and cropping pattern various methods have used by scholars, scientists and geographers. Among them J.C.Weavers method is selected in present investigation. Weaver in 1954 has applied least standard deviation technique for computing crop combination region. $\mathrm{He}$ demarcated agriculture regions applying statistical method, on the basis of percentage of crops and their associations. According to them crop always exist in association. His formulation has very simple. First, the percentage of each crop of the selected crops to the total cropped area is determined. Then each percentage is considered against a standard norm and with the help of standard deviation, the right crop combination is determined.

\section{Study Area}

The present study deals with the geographical perspectives of the agriculture in Solapur district.
The Solapur district is bounded by $17^{\circ} 05^{\prime}$ North latitudes to $18^{\circ} 32^{\prime}$ North latitudes and $74^{\circ} 42^{\prime}$ East of $76^{\circ} 15^{\prime}$ East longitudes. The total geographical area of Solapur district is $14895^{2}$ K.m. divided into eleven tahsils. The Population is 32.4 lakhs in eleven tahsils of District. (Censes 2001). It is bounded from the North by Osmanabad district and Ahmednagar district, on the North-East by Satara district and at the South \& East it has common boundary of Karanataka state. Temperature is high in summer season. Rainfall varies from East to West between range of 200 to 600 millimeters. The rivers like Bhima, Sina, Man, Nira Bhogawati and many other smaller tributaries drain in the district. The soil of the district is mainly of DeccanTrap Volcanic origin. It is underlined by partially decomposed Basolatic rock material locally known as "murum" (Fig 1) Objectives

The major object of this paper is to assess the cropping pattern, crop ranking and crop combination regions in Solapur District of Maharashtra.

\section{Database and Methodology}

Present study mostly relies on the secondary data collected through Agriculture Department and District statistical Department of Solapur and District socio-economic abstract of Solapur District. For the present investigation, District is selected as in general and tahsils in particular. Simple statistical method has used to compute crop ranking and Weavers Crop combination technique in present study. 
In order to assess the crop combination, the following formula has been adopted.

$$
\mathrm{d}=\frac{\Sigma \mathrm{d}^{2}}{\mathrm{n}}
$$

Where'd' is the difference between the crop percentage in a given country (areal unit) and the appropriate percentage in the theoretical curve and ' $n$ ' is the number of crops in a given combination.

\section{Concept of Agriculture Land-Use}

Agriculture land-use means land under net sown area, fallow land and uncultivable land excluding fallow land. The cultivated area is known as net sown area, which is also known as agriculture land. In short agriculture land-use means a cropping pattern. Copping pattern means the proportion of area under various crops at a point of time or yearly sequence and spatial arrangement of crops and fallow on a given area. Cropping pattern is a dynamic concept as it changes over space and time. The cropping patterns of a region are closely influenced by the geoclimatic, sociocultural, economic, historical and political factors. The agriculture landuse is the result of the direct application of efforts applied is related to decisions made by farmer regarding the actual use of land. These decisions are based on his appreciation of the available land resources, his response to these resources as conditioned by the knowledge passed from generation to generation and his appreciation of demand for various agriculture commodities in the market. The cumulative effect of farmer's decision regarding the choice of crops, the method of tillage and his appreciation of the land resources is reflected in the spatial as well as temporal variation in agriculture landuse.

\section{Need of Agriculture Landuse Study \\ - To feed the man's requirement. \\ - To study the landuse problem. \\ - For keeping social and ecological balance. \\ - For best use of land. \\ - For optimum use of land.}

\section{Agriculture landuse/ cropping pattern}

The agriculture land in Solapur district is 65.50 percent of the total geographical area which includes 63.50 percent area of the net sown area and 2.42 percent area is shown more than once. Cropping pattern of district is typical that the food crops cover most of the cultivated area. In the study region food crops occupy largest area, which is 87.04 percent of the total net sown area in 2004-05, which Jawar is leading crop followed by wheat and other food grains that occupy a small proportion of area. Jowar is the main rabbi crop, which is grown from September to February throughout the region. Jowar, is also grown as a kharif crop in some tahsils. Wheat is rabii crop cultivated in irrigated area and kharif crop bajara is grown in drought prone area. Nevertheless, sugarcane has now attained a significant proportion i.e., 8.30 percent. Sugarcane is main cash crop, which is mainly cultivated in guaranteed irrigated area of the region. Among non-food crops groundnut and safflower and fodder occupy a dominant place.

\section{Ranking of Crops}

Ranking of crops depends on insight in the geographical reality and cropping structure. The percentage of gross cropped land with the aerial strength of a particular crop reveals the agricultural operation involved, period of peak, labours demand and the opportunities of employment to the farmer's families as well as to the labour depending on them. Ranking of crops also indicates the nature of enterprise i.e., whether the particular aerial units are of traditional subsistent farmers or commercially market-oriented or partly subsistent and partly market oriented farmers. In this method, the first ranking crop, i.e., the crop occupying the highest percentage of the total cropped area in each of the component areal units could be chosen. It may be noticed from Table No 1 that Jawar ranks first in all the eleven tahsil of the district. In second ranking crop wheat, sugarcane and tur major crops. The sugarcane and gram prefers in third and bajara, gram are fourth rank. Fig. 3 indicates the rank frequency of sugarcane, bajara, wheat, gram, tur and safflower in study area.

\section{Crop Combination}

Weaver's method has been admirably accepted for the delineation of crop combination regions as its application result is suitable for combination. The method, however, gives the most unwieldy combination for the units of high crop specification. As a result of the application of the Weaver's method, ten crop combination regions emerge out in Solapur district. Therefore, the scale of cumulative percentage starts from above 50 per cent which is contributed high rank may be first one called 'Monoculture', two or three crop combination and so on.

Jawar crop is the monoculture crop in two tahsils of the region i.e., Mangalwedha and North Solapur. Mangalwedha is famous for maladandi jawar, black soil and lack of irrigation facilities responsible for them. In North Solapur there is no guaranteed source of water and rainfall is below $1500 \mathrm{~mm}$, however the area of jawar crop is large. Madha taluka is marked with four crop combination i.e., jawar, gram, groundnut and safflower. Six crop combination is observed in Malshiras tahsil i.e., jawar, wheat, sugarcane, maize, gram and bajara crop. Pandharpur taluka 
comes under seven crop combination. Hence, jawar, wheat, sugarcane, maize, gram, fruit and bajara crops have come in this combination. Pandharpur taluka is located in the central part of the district. Bhima river is the main source of irrigation, which flows from northwest to southeast. Nira and Ujani canals are also available for irrigation. Soil is shallow to deep black. Six talukas shows ten crop combination. These talukas belong to the northeast and eastern part of the district, where rainfall is medium (below $600 \mathrm{~mm}$ ) and soil varies from black to coarsec shallow. It has also some area under well irrigation. These talukas are noted for with jawar, sugarcane, groundnut, safflower, wheat, maize, gram, bajara, tur and fruits combination. In Akkalkot maize crop is absence and cotton crop is found there. All the above factors affect diversification of crop combination and distribution pattern of crops.

\section{Concluding Remarks}

In case of ranking of crops first ranking crops in Solapur district is jowar. In second ranking crop wheat, sugarcane and tur major crops. The sugarcane and gram prefers in third and bajara , gram are fourth rank. Fig. 2 indicates the rank frequency of sugarcane, bajara, wheat, gram, tur and safflower in study area. Weaver's method has identified ten crop combinations in study region. Jowar as monoculture has found in Mangalwedha and North Solapur tahsils in study region. Four crop combination appeared in Madha tahsil. Six crop combination is observed in Malshiras tahsil i.e., jawar, wheat, sugarcane, maize, gram and bajara crop. Pandharpur taluka comes under seven crop combination. Six talukas shows ten crop combination. These talukas are noted for with jawar, sugarcane, groundnut, safflower, wheat, maize, gram, bajara, tur and fruits combination. The problems of agriculture landuse planning are envisaged by the extension of agriculture land, raising the productivity of land, soil conservation, improved seeds, pesticides, plant protection and better agriculture implements, change in the crop distribution and agro based industries in the study region.

\section{References}

[1] Das M.M. (1990) Agriculture Land use and cropping pattern

[2] Balak, Ram and Joshi D.C. (1984) Landuse Soil Relationship in Arid Zone. The Deccan Geographer Vol-XXII

[3] Bharadwaj O. P. (1964) The national Geographical Journal of India. 10,2.

[4] Hussan M. (1999) Systematic Agriculture Geography. Rawat Publication

[5] Kapadnis N. R. (1991) Spatial analysis of agriculture land-use in relation to environmental factors in Nashik District; Unpublished Ph.D. thesis submitted to A.P.S. University, Rewa(M.P.)

[6] Kashid P. B. (2005) A agricultural Land Use in Solapur District ; A Geographical Analysis .M Phil dissertation submitted to Nanded University

[7] Majid Hussain (2004) Agriculture Geography, Rawat Publication

[8] Mohammad Shafi (2006) Agriculture Geography. Pearson Education

[9] Patil S.L. (1988) A Study of changing cropping with special reference to horticulture in Sangola taluka, unpublished M.Phil dissertation submitted to Shivaji University, Kolhapur. 
Agriculture Landuse Pattern in Solapur District of Maharashtra

Table No 1: Crop Ranks and Number of Tahsils in Solapur District

\begin{tabular}{|cllllllc|}
\hline Sr. No. & Crops & Rank I & Rank II & Rank III & Rank IV & Rank V & Rank VI \\
\hline 1 & Jowar & 11 & - & - & - & - & - \\
2 & Wheat & - & 2 & 2 & 2 & - & 2 \\
3 & Maize & - & 1 & - & 2 & - & 1 \\
4 & Bajara & - & - & 2 & 3 & 3 & 2 \\
5 & Sugarcane & - & 2 & 3 & - & - & - \\
6 & Tur & - & 2 & - & - & 2 & 1 \\
7 & Gram & - & 1 & 3 & 3 & 2 & - \\
8 & Safflower & - & 1 & - & 1 & 1 & 2 \\
9 & Groundnut & - & - & 1 & - & 2 & \\
\hline
\end{tabular}

Source :- Compiled by Author

Table No. 2: Crop Combination regions in Solapur District

\begin{tabular}{|lcc|}
\hline Crop Combination & Name of Crops & No. of Villages \\
\hline Monoculture/ one crop & $\mathrm{Ja}$ & 2 \\
Four crop region & $\mathrm{Ja}+\mathrm{Gm}+\mathrm{Gr}+\mathrm{Sa}$ & 1 \\
Six crop region & $\mathrm{Ja}+\mathrm{Wh}+\mathrm{Su}+\mathrm{Ma}+\mathrm{Gm}+\mathrm{Ba}$ & 1 \\
Seven crop region & $\mathrm{Ja}+\mathrm{Wh}+\mathrm{Sa}+\mathrm{Ma}+\mathrm{Gm}+\mathrm{Fr}+\mathrm{Ba}$ & 1 \\
ten crop region & $\mathrm{Ja}+\mathrm{Wh}+\mathrm{Su}+\mathrm{Ma}+\mathrm{Gm}+\mathrm{Fr}+\mathrm{Ba}+\mathrm{Tr}+\mathrm{Gr}+\mathrm{Co}+\mathrm{Sa}$ & 6 \\
\hline
\end{tabular}

Source: - Compiled by Author

Note: $\mathrm{Ja}=$ jawar, $\mathrm{Wh}=$ wheat, $\mathrm{Sa}=$ safflower, $\mathrm{Ma}=$ maize, $\mathrm{Gm}=\mathrm{gram}, \mathrm{Fr}=$ fruit, $\mathrm{Ba}=$ bajara, $\mathrm{Tr}=\mathrm{tur}, \mathrm{Gr}=$ groundnut, $\mathrm{Gm}=$ gram, $\mathrm{Co}=$ cotton 


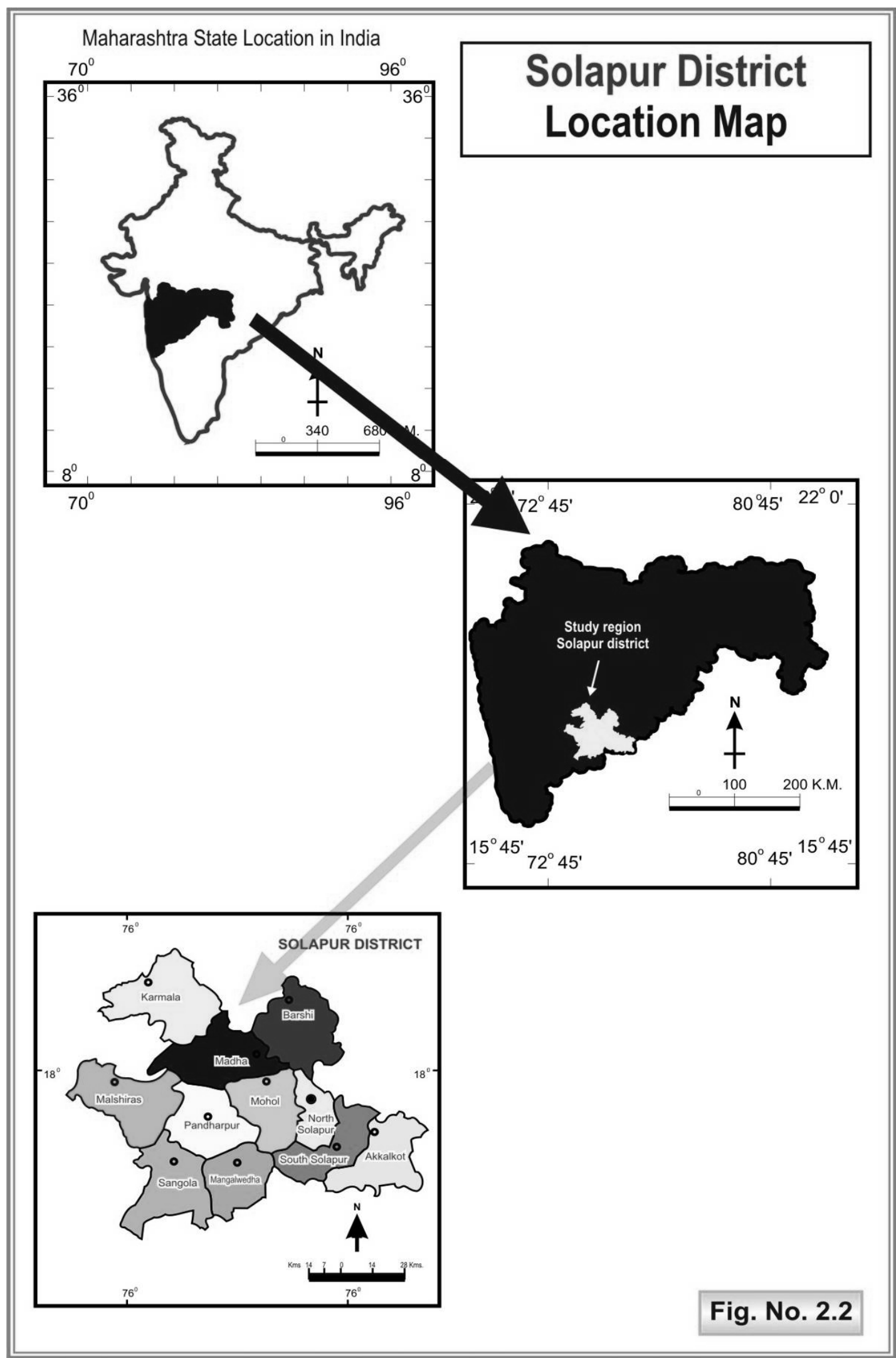

Fig. 1- Solapur District map 


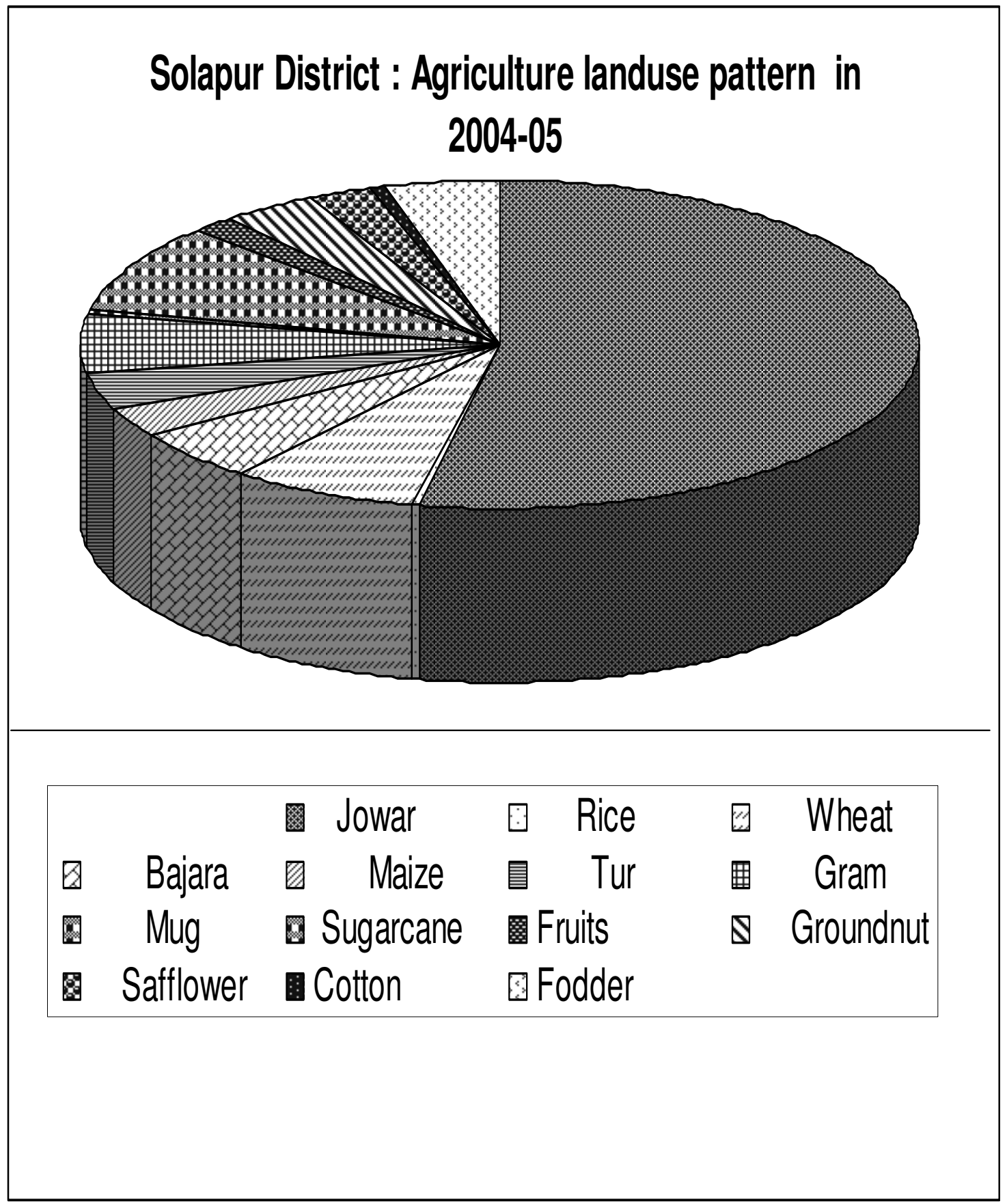

Fig. 2- Solapur District: Agriculture landuse pattern in 2004-05 


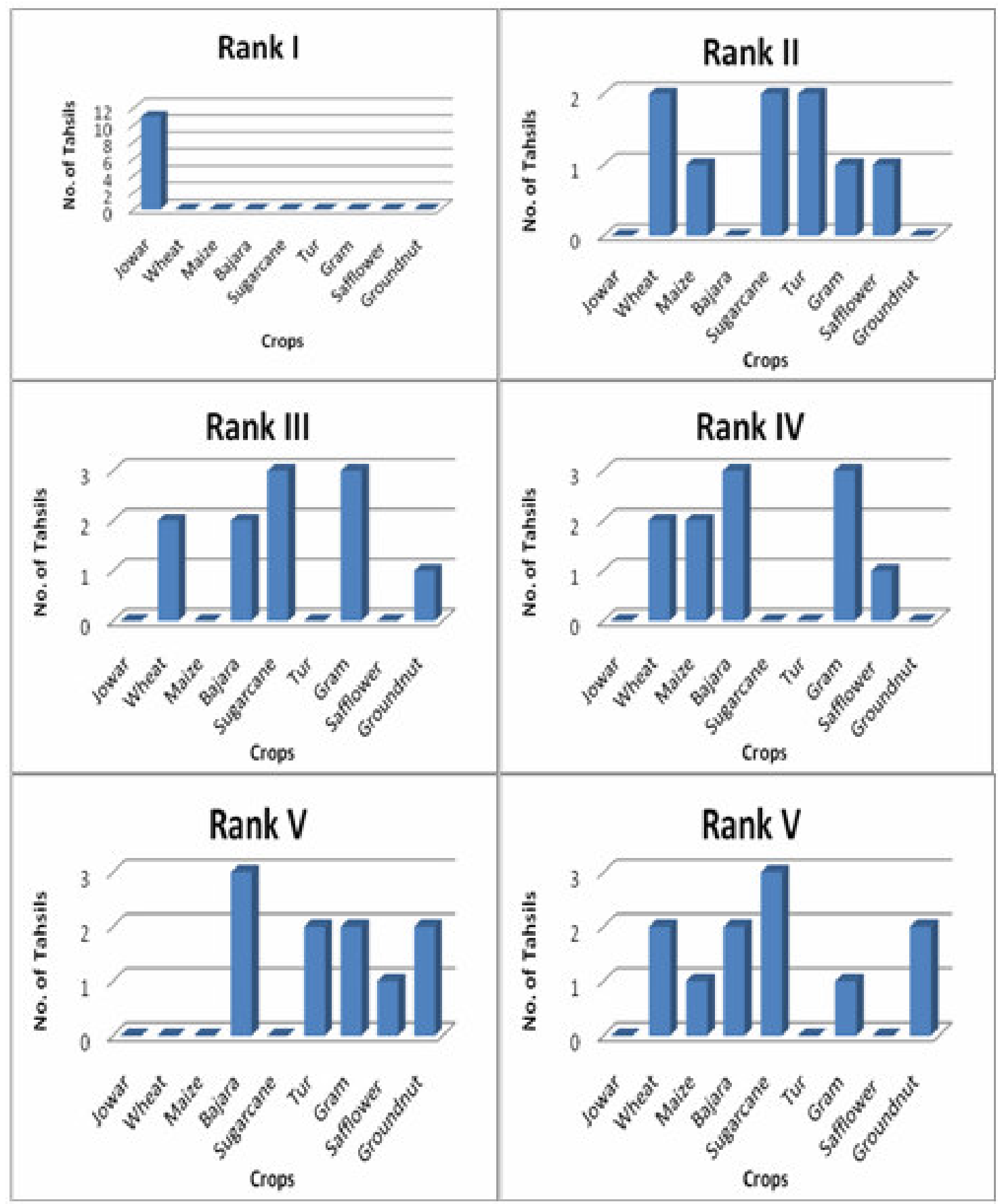

Fig. 3- Crop Ranking In Solapur District 


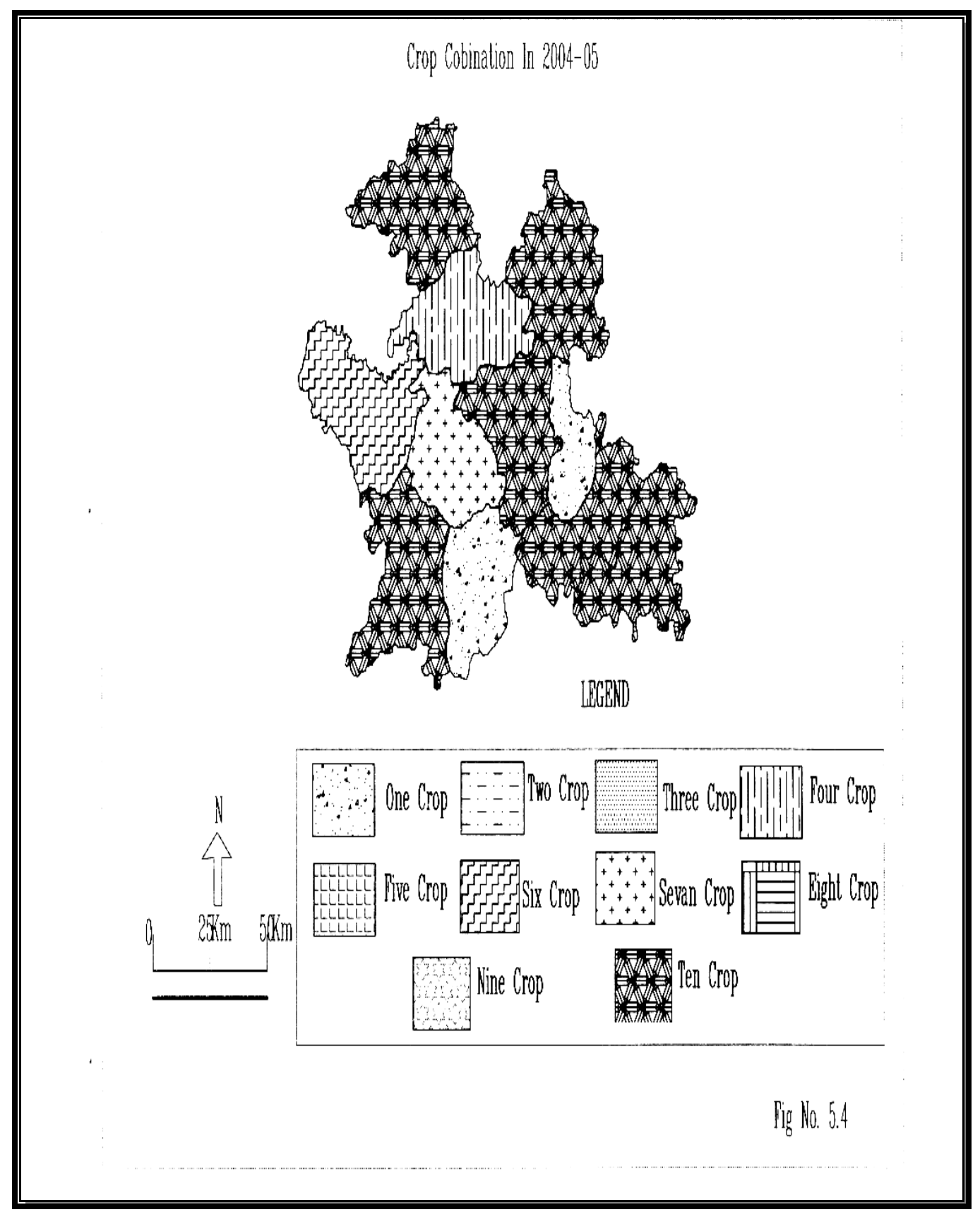

Fig. 4- Crop combination in 2004-05 